\title{
Effect of Herbicide Sweep Power (Glufosinate Ammonium) on Total Protein Content in Different Tissues of Freshwater Fish Labeo rohita
}

\author{
Manjiri A. More ${ }^{1}$, Narayan R. Mane ${ }^{1 *}$ \\ ${ }^{1}$ Assistant Professor, Department of Zoology, Gopal Krishna Gokhale College Kolhapur, India
}

*Address for Correspondence: Dr. Narayan R. Mane, Assistant Professor, Department of Zoology, Gopal Krishna Gokhale College Kolhapur, India

E-mail: manenarayan.136@rediffmail.com

Received: 24 Dec 2020/ Revised: 12 Feb 2021/ Accepted: 10 Apr 2021

\begin{abstract}
Background: Sweep power (Glufosinate Ammonium) is the most commonly used herbicide in agriculture crop field to remove numerous weeds. Nowadays, the use of herbicides was increased in agriculture as well as an industrial area. Due to runoff water, these herbicides arrived at the nearest natural water bodies such as ponds, lakes, rivers etc. and adversely effect on the nontarget organism.

Methods: In the present study, the freshwater fishes Labeo rohita were acclimatized in a glass aquarium and exposed to predetermined $\mathrm{LC}_{0}$ and $\mathrm{LC}_{50}$ concentration $(0.01 \mathrm{ppm}$ and $0.05 \mathrm{ppm}$ respectively) of herbicide sweep power (Glufosinate Ammonium) for 96 hours. The amount of total protein content from different tissue of fishes from each experimental group was estimated.

Results: It was observed that the total protein content in gills, liver, muscle, and brain tissues were significantly decreased in LC 0 and $\mathrm{LC}_{50}$ concentration group as compared to the control group.

Conclusion: From the present study, it confirms that the selected herbicide Sweep power (Glufosinate Ammonium), do interfere with normal metabolism and biochemical composition in freshwater fishes L. rohita.
\end{abstract}

Key-words: Glufosinate Ammonium, Herbicides, Labeo rohita, Protein, Sweep power

\section{INTRODUCTION}

Now-a-day numerous herbicides are used for the controlling of crop weeds. Most of the herbicides available in the market are synthetic, which is one of the major causes of water pollution. This is widely used to control weed and herbaceous pests. But, it greatly affects the quality and quantity of food production. These synthetic herbicides are directly used in the agricultural field and due to runoff water and soil erosion arrives at nearly water bodies such as a river, ponds, lakes, etc ${ }^{[1]}$. This can result in the accumulation of a large amount of herbicides in such water bodies. The normal aquatic flora and fauna including the fishes are greatly affected to change in the environment.

\section{How to cite this article}

More MA, Mane NR. Effect of Herbicide Sweep Power (Glufosinate Ammonium) on Total Protein Content in Different Tissues of Freshwater Fish Labeo rohita. SSR Inst. Int. J. Life Sci., 2021; 7(3): 2813-2817.

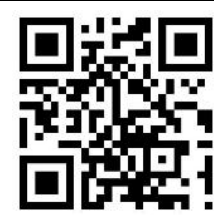

The fishes are directly exposed to the aquatic environment and accumulate various toxic compounds in organs. The toxic chemicals easily penetrate the fish's body by various routes such as direct contact, respiration by gills and food. The feeding of poisoned insect and other fishes is one of the secondary causes of exposure. They are adverse effects on the normal function, growth, behaviour and physiology of the fishes because of low degradability, high rate of accumulation inside the aquatic fauna and long term persistence ${ }^{[2]}$.

Glufosinate ammonium is a highly effective herbicide used to control weeds in more than 100 crops in many countries worldwide. Farmers rely on Glufosinateammonium because it ensures a high degree of crop safety, as it only affects the parts of the plant where it is applied. Glufosinate ammonium was first brought to market in 1984. Today it is registered for use to control weeds in a variety of crops worldwide, including soybeans, corn, canola and cotton, which have been modified through genetic engineering to be tolerant to Glufosinate-ammonium. 
Proteins are a fundamental biochemical component and available in huge amount in fishes. Fishes have an important role in the diet because of the rich protein source and their socioeconomic role for humans [3]. Analysis of protein content in fishes helps to analyze healthy growth and nutritional value. The study of protein content in the fish body used to be understood under the stressful conditions and ability of fishes to overcome the toxic effects of toxicants, metabolic activity and movement during spawning.

Therefore, the present study was undertaken to evaluate the effect of lethal concentrations of sweep power (Glufosinate Ammonium) on total protein content in fingerlings of freshwater fish L. rohita.

\section{MATERIALS AND METHODS}

The present study was conducted in the Department of Zoology, Gopal Krishna Gokhale College Kolhapur, India from June 2019 to December 2020.

Experimental fish and laboratory condition- The fingerlings of freshwater fish $L$. rohita $(6 \pm 8 \mathrm{~cm}$ in length and 9-11 $\mathrm{g}$ in weight) were collected from the local supplier from Kolhapur. Before the acclimatization in laboratory condition, fingerlings were offering a bath with a disinfectant solution to avert bruise and disease. After disinfection fish were maintained in glass aquaria at $26 \pm 2^{\circ} \mathrm{C}$ temperature, 12 hours light and 12 hours dark cycle with supplying continuous aeration for 15 days. The fishes were fed every day with commercially available fish food.

\section{RESULTS}

The result of the effect of sweep power (Glufosinate Ammonium) on the total protein in various organs viz. gill, muscle, liver, brain of the fish L. rohita in the control
Toxicity Test- The insecticide sweep power (Glufosinate Ammonium) was purchased from M/S Super Bio Tech Marketing Company, India. A well-acclimatized healthy fishes were selected for the present study. The toxicity test was carried out in 20 liter plastic trough. In each trough, ten fishes were released. The trough was distinguished into three groups viz. Control group (Without any exposure of toxicant); LC Concentration group (exposed to $0.01 \mathrm{ppm}$ concentration of sweep power) and $\mathrm{LC}_{50}$ concentration group (exposed to 0.05 ppm concentration of sweep power). After 24hrs, the experimental medium was replaced by a fresh medium.

Estimation of Total protein content- After 96 hours of exposures, the fishes from each group were sacrificed and total protein content was estimated by the Lowry method ${ }^{[4]}$ from gill, liver, muscle and brain tissues.

Statistical analysis- The observed data from each group were expressed in arithmetic meantstandard deviation. The level of significance was calculated using the student's t-test.

Ethical approval- All the experimental procedures were carried out with due permission of the Institutional Animal Ethics Committee, Gopal Krishna Gokhale College Kolhapur, India.

group, $\mathrm{LC}_{0}$ concentration group and $\mathrm{LC}_{50}$ concentration group after acute exposure (96 hours) are depicted in Table 1 and Fig. 1.

Table 1: Total protein content in different tissues of the fish L. rohita after acute exposure sweep power (Glufosinate ammonium)

\begin{tabular}{ccccc}
\hline \multirow{2}{*}{ Groups } & \multicolumn{3}{c}{ Amount of total protein ( $\mu$ p protein/mg wet wt. of tissue) } \\
\cline { 2 - 4 } & Gill & Liver & Muscle & Brain \\
\hline Control & $24.1 \pm 0.37$ & $39 \pm 0.28$ & $38.7 \pm 0.33$ & $29.9 \pm 0.37$ \\
LC & $21 \pm 0.28^{* * *}$ & $32.67 \pm 0.33^{* * *}$ & $36.1 \pm 0.37^{* * *}$ & $26.97 \pm 0.29^{* * *}$ \\
LC & $13.6 \pm 1.23^{* * *}$ & $31.23 \pm 0.46^{* * *}$ & $23.63 \pm 0.29^{* * *}$ & $18.07 \pm 0.43^{* * *}$ \\
\hline
\end{tabular}




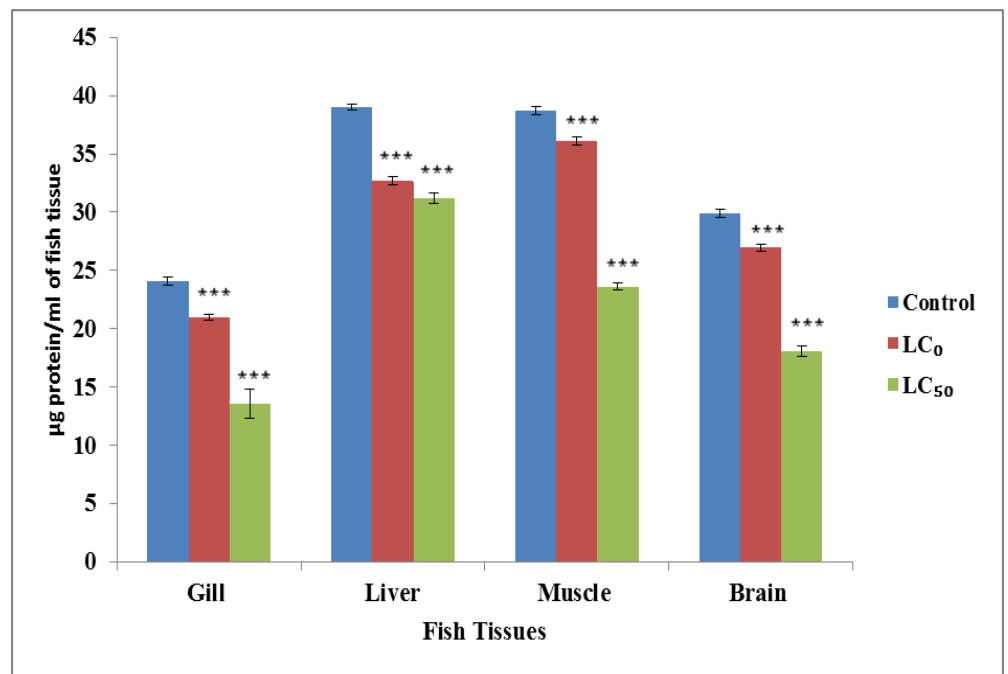

Fig. 1: Total protein content in different tissues of the fish L. rohita after acute exposure sweep power (Glufosinate ammonium); Values expressed as Arithmetic Mean of $(n=5) \pm S D, * * *=P<0.001$

\section{DISCUSSION}

In the present study, observed the toxicological effect of the agrochemical herbicide Sweep Power (Glufosinate Ammonium) using total protein in the freshwater fish $L$. rohita. Sweep Power is the most recently used herbicides practised in many agriculture and industrial fields. The major component of Sweep Power herbicide is Glufosinate Ammonium. The Glufosinate Ammonium containing herbicides are also used as a pre-harvest desiccant for a variety of crops including potatoes, peas, soybeans and cereals ${ }^{[5]}$. Nowadays, it is also increasingly being used as a selective herbicides plant on transgenic crops ${ }^{[6,7]}$. The Glufosinate Ammonium acts by blocking the enzymes involved in the synthesis of amino acid glutamine. Inhibition of glutamate synthesis has been reported not only in plants but also in animals and humans ${ }^{[5,8]}$. Watanabe and Iwase ${ }^{[9]}$ were reported the toxic effect of Glufosinate Ammonium on mammalian brain cells both in vivo and in vitro, in response to the release of excessive glutamic acid. Recent studies have been observed the exposure of Glufosinate Ammonium leads to the accumulation of free radicals and increased lipid peroxidation ${ }^{[10]}$. Due to runoff water, Glufosinate Ammonium, which is excessively used in agriculture field reaches natural water recourses, which harms nontarget organism such as larvae of clams, oysters, daphnia, and several species of freshwater fish ${ }^{[11-14]}$. An excessive amount of Glufosinate Ammonium has been reported in agricultural soil, groundwater and stable water ${ }^{[15,16]}$.
In the present investigation, the amount of total protein content was significantly decreased in all tissues (gills, liver, muscle and brain) of fish $L$. rohita in all experimental groups ( $\mathrm{LC}_{0}$ and $\mathrm{LC}_{50}$ concentration group) as compared to the control group. Similar results were noted by various toxicity studies in fishes. Veeraiah et al. [17] revealed a significant decrease in total protein in freshwater fish $L$. rohita exposed to acute and chronic concentrations of pesticide Indoxacarb $\left(L_{5} C_{50}=0.0531\right)$. Lekeshmanaswamy ${ }^{[18]}$ reported that the sub-lethal dose of malathion in the exposed freshwater fish $L$. rohita showed a decline in protein content. Decreased levels of protein in gills, liver, brain and muscle of Cirrhinus mrigala under the acute concentration of methanol reported by Desai and Bhilave ${ }^{[19]}$. Prakash and Verma ${ }^{[20]}$ observed a gradual decrease in protein content in the liver and muscles of catfish (Mystus vittatus) exposed to sub-lethal concentration of arsenic.

In the present study, the decrease in total protein content in various tissues of fish L. rohita is might be due to increased stressful conditions by acute intoxication of selected herbicide [21]. To cope with this insecticides stress, fishes demand more energy and this result in increased proteolysis [22]. Chandravathy and Reddy [23] reported the decreased total protein content in muscle tissue is due to inhibition of protein synthesis, elevated protein degradation and increased protein utilization for various metabolic reactions under stress. Reduction in the protein content in tissue is due to increased proteolysis and utilization of products for various metabolic reactions. Due to insecticide toxicity, there 
may be increased necrosis of tissues, damage of cellular membranes, cytoplasmic vacuolation, cellular degradations, etc. This can result in the depletion of protein owing to the utilization of protein for cell repair system ${ }^{[24]}$.

\section{CONCLUSIONS}

A decrease in the total protein level in the present investigation in L. rohita indicated that the gill, liver, muscle and brain tissue protein might have proteolysis activity, stressful condition, increased catabolic reaction and protein synthesis to fulfil increased energy demand during the acute toxic condition of herbicide Sweep Power (Glufosinate Ammonium).

Further studies were required for the effect of Glufosinate Ammonium at the molecular level in freshwater fish L. rohita and other non-target animals.

\section{CONTRIBUTION OF AUTHORS}

Research concept- Dr. Manjiri A. More, Dr. Narayan R. Mane

Research design- Dr. Manjiri A. More, Dr. Narayan R. Mane

Supervision- Dr. Manjiri A. More, Dr. Narayan R. Mane

Materials- Dr. Manjiri A. More, Dr. Narayan R. Mane

Data collection- Dr. Manjiri A. More, Dr. Narayan R. Mane

Data analysis and interpretation- Dr. Manjiri A. More, Dr. Narayan R. Mane

Literature search- Dr. Manjiri A. More, Dr. Narayan R. Mane

Writing article- Dr. Manjiri A. More, Dr. Narayan R. Mane

Critical review- Dr. Manjiri A. More, Dr. Narayan R. Mane Article editing- Dr. Manjiri A. More.

Final approval- Dr. Manjiri A. More, Dr. Narayan R. Mane

\section{REFERENCES}

[1] Liu W, Gan JJ, Lee S, Kabashima JN. Phase distribution of synthetic pyrethroids in runoff and stream water. Environ Toxicol Chem., 2004; (1): 7-11.

[2] Mintram KS, Maynard SK, Brown AR, Boyd R, Johnston AS, et al. Applying a mechanistic model to predict interacting effects of chemical exposure and food availability on fish populations. Aquat Toxicol., 2020; 224: 105483.

[3] Massey LK. Dietary animal and plant protein and human bone health: a whole foods approach. J Nutr., 2000; 133(3): 862S-5S.
[4] Lowry OH, Rosenber NJ, Farr AL, Randal RJ. Protein measurement with Folin phenol reagent. J Biochem., 1951; 193: 265-75.

[5] Kang GR, Song HY, Kim DS. Toxicity and effects of the herbicide glufosinate-ammonium (Basta) on the marine medaka Oryzias dancena. J Fish Aquat Sci., 2014; 17(1): 105-13.

[6] Duke SO, Cerdeira AL. Transgenic crops for herbicide resistance. In Transgenic crop plants. Springer, Berlin, Heidelberg, 2010; pp. 133-66.

[7] Andreassen ÅK, Bakke AM, Dahl KK, Dalen KT, Finne $M A$, et al. Final Health and Environmental Risk Assessment of Genetically Modified Soybean A5547127. Eur J Nutr Food Saf., 2021: 130-31.

[8] Cox C. Herbicide factsheet: glufosinate. Journal of pesticide reform: a publication of the Northwest Coalition for Alternatives to Pesticides (USA), 1996.

[9] Watanabe T, Iwase T. Developmental and dysmorphogenic effects of glufosinate ammonium on mouse embryos in culture. Teratog carcinog mutagen, 1996; 16(6): 287-99.

[10]Takano HK, Dayan FE. Glufosinate-ammonium: a review of the current state of knowledge. Pest Manag. Sci., 2020; 76(12): 3911-25.

[11]Qian H, Chen W, Sheng GD, Xu X, Liu W, et al. Effects of glufosinate on antioxidant enzymes, subcellular structure, and gene expression in the unicellular green alga Chlorella vulgaris. Aquat Toxicol., 2008; 88(4): 301-07.

[12]Peltzer PM, Junges CM, Attademo AM, Bassó $A$, Grenón P, Lajmanovich RC. Cholinesterase activities and behavioral changes in Hypsiboas pulchellus (Anura: Hylidae) tadpoles exposed to glufosinate ammonium herbicide. Ecotoxicol., 2013; 22(7): 116573.

[13] Lajmanovich RC, Cabagna-Zenklusen MC, Attademo AM, Junges CM, Peltzer PM, Bassó A, Lorenzatti E. Induction of micronuclei and nuclear abnormalities in tadpoles of the common toad (Rhinella arenarum) treated with the herbicides Liberty and glufosinateammonium. Mutat Res Gen Tox En., 2014; 769: 7-12.

[14]Xiong G, Deng Y, Li J, Cao Z, Liao X, Liu Y, Lu H. Immunotoxicity and transcriptome analysis of zebrafish embryos in response to glufosinateammonium exposure. Chemosphere, 2019; 236:124423.

[15]Ferrari S, Mettifogo OS, Cunha ML, dos Santos Cordeiro LF, do Valle Polycarpo G, et al. Effects of Low Doses of Glufosinate-Ammonium on Upland Rice Agronomic Traits. Gesunde Pflanzen., 2021: 1.

[16]Geng $Y$, Jiang L, Zhang D, Liu B, Zhang J, et al. Glyphosate, aminomethylphosphonic acid, and glufosinate ammonium in agricultural groundwater and surface water in China from 2017 to 2018: 
Occurrence, main drivers, and environmental risk assessment. Sci Total Environ., 2021; 769: 144396.

[17]Veeraiah K, Padmavathi P, Rao ST, Vivek CH. Methyl parathion $(50 \% \mathrm{EC})$ induced changes in protein and DNA banding patterns in the fish Channa punctatus (Bloch). Int J Bioassays, 2014; 4: 3632.

[18] Lekeshmanaswamy $M$. studies on the impact of a malathion insecticide on certain biochemical constituents of a freshwater fish, Labeo rohita. Kong. Res. J., 2018; 5(1): 93-96.

[19]Desai T, Bhilave M. Toxicological Effect of Methanol on Protein Profile of Freshwater fish Cirrhinus mrigala. IJRA, 2019; 6(2): 309-20.

[20]Prakash SA, Verma AK. Impact of Arsenic on Protein Metabolism of a fresh water cat fish, Mystus vittatus. UPJOZ, 2020; 41(5): 16-19.
[21]Somaiah K, Satish PV, Sunita K, Nagaraju B, Oyebola OO. Toxic impact of phenthoate on protein and glycogen levels in certain tissues of Indian major carp Labeo rohita (Hamilton). IOSR J Environ Sci Toxicol Food Technol., 2014; 8: 65-73.

[22] Pazhanisamy K, Indra N. Toxic effects of arsenic on protein content in the fish, Labeo rohita (Hamilton). Nat Environ Pollut Technol., 2007; 6(1); 113-16.

[23] Chandravathy VM, Reddy SL. In vivo recovery of protein metabolism in gill and brain of a freshwater fish, Anabas scandens after exposure to lead nitrate. J Environ Biol., 1994; 15(1): 75-82.

[24]Lecker SH, Goldberg AL, Mitch WE. Protein degradation by the ubiquitin-proteasome pathway in normal and disease states. J Am Soc Nephrol., 2006; 17(7): 1807-19. 